\title{
V-Set and Immunoglobulin-Domain Containing Protein 10-Like
}

National Cancer Institute

\section{Source}

National Cancer Institute. V-Set and Immunoglobulin-Domain Containing Protein 10-Like. NCI Thesaurus. Code C132157.

V-set and immunoglobulin domain-containing protein 10-like (867 aa, 92 kDa) is encoded by the human VSIG10L gene. This protein may play a role in cell-cell junction formation. 